teologer, og i reformationsårhundredet især af lutherske teologer. Forf. vil med nærværende bog se nærmere på det billede, disse skrifter tegner af muslimerne og i særlig grad, hvordan forfatterne beskrev og vurderede deres religion. Forf. afviser at hans hensigt skulle være at bidrage til den aktuelle debat.

Efter nogle metodologiske overvejelser beskæftiger forf. sig først med skrifternes oplysninger om den tyrkiske religion, om enkelte religiøse højtideligheder, skikke, bygninger, om koranen og om personen Muhammed. Dernæst skildres skrifternes anvendelse internt i kristendommen af det tegnede skrækbillede, dvs. hvorledes kristne af begge konfessioner kunne foretage en tyrkisering af modstandere inden for kristendommen. Videre undersøges forholdet i 1500-tallet mellem billedet af tyrken og den europæiske identitet, de eskatologiske perspektiver og den eventuelle sammenhæng mellem tyrkerfaren og den protestantiske reformations udbredelse. Bogen er opbygget på den måde, at forf. først behandler disse, og adskillige andre, emner i en tekstdel på godt 60 sider. Derefter følger godt 30 sider med billeder, som efterfølges af bogens største afsnit, Anmerkungen. Ikke færre end 613, som fylder 128 sider. Nogle af disse noter fylder et par sider. Her citeres længere uddrag af de pågældende skrifter, andre udsagn fra andre samtidige skrifter tilføjes, ligesom der i hvert enkelt tilfælde bringes fyldige oplysninger om relevante, nyere forskningslitteratur og kildeudgivelser. Endelig findes fortegnelser over de behandlede kildeskrifter og forskningslitteraturen samt registre.

De mange skrifter vil bringe "objektive" oplysninger om islam, men bygger ikke på Koranen, men på rejseoplevelser, tilfangetagnes oplysninger og lignende. De vil samtidig forsvare kristendommen og opfordre de kristne til bod og alvorligt kristenliv. Tyrken blev ganske vist opfattet som Guds svøbe på grund af de kristnes slette levned, et tegn på de eskatologiske tiders begyndelse, men samtidig kunne både lutherske og katolske enes om militært at bekæmpe tyrkerne, og dette skulle ske under - den katolske - kejsers ledelse. Trods dette dristede de lutherske fyrster sig til at kræve indrømmelser mht. deres gennemførte reformationer, dersom de skulle deltage militært.

Bogen bringer et væld af oplysninger fra et kildemateriale, som for de flestes vedkommende ellers er svært tilgængelig. Desuden er det en guldgrube af henvisninger til nyere forskningslitteratur.

Martin Schwarz Lausten

\title{
Johann Gerhard
}

Exercitium pietatis quotidianum quadripartitum (1612). Latin - Tysk. Udg. og komm. af Johann Anselm Steiger. Doctrina et pietatis. Abt. I Johann Gerhard-Archiv 12. Stuttgart-Bad Cannstadt: frommann-holzboog 2008. 519 s. 4 ill. € 498. 
Tractatus de legitima scripturae sacrae interpretatione (1610). Latin - Tysk. Udg. og komm. af Johann Anselm Steiger og Vanessa von der Lieth. Doctrina et pietatis Abt. I. Johann Gerhard-Archiv 13. Stuttgart-Bad Cannstadt: frommann-holzboog 2007.541 s. 5 ill. € 498.

Med disse to bind i Doctrina et pietatis-serien fra frommann-holzboog er to væsentlige kilder til den lutherske ortodoksis begyndelse blevet tilgængelige i fine tekstkritiske udgave. Begge værker findes i samtidige tyske oversættelser, som bringes parallelt med den latinske tekst. Kvaliteten er høj. Det samme er prisen.

Begge bøger stammer fra Johann Gerhards tid som superintendent i Heldburg. Hvor traktaten om den rette fortolkning af den hellige skrift er til akademisk brug, er bønnebogen til det personlige fromhedsliv. Begge bøger får stor betydning i den lutherske barok, hvor såvel skrifthermeneutik som bønnebog vinder stor udbredelse. Læst sammen giver de derfor et glimrende og facetteret billede af den allertidligste "ortodoksi". Ortodoksiens skriftprincip ses i Tractatus udfoldet med stringens og en stilistisk sikker pen, mens bønnebogen endnu gang understreger, at ortodoksien på ingen måde var livløs.

Tractatus indgik i langt de fleste udgaver af Gerhards Loci theologici, et af den lutherske ortodoksis mest markante hovedværker og den første lutherske dogmatik. Samtidig har vi med udgivelsen af Tractatus fået adgang til et værk, som ellers kun med vanskelighed har kunnet læses, men som har haft stor betydning for hermeneutikkens udvikling fra reformationen og frem mod oplysningstiden. Hos Gerhard udfoldes skriftprincippet på en måde, der forener den metodiske bevidsthed med en klar teologi. Værket begynder med en bekendelse til skriftens klarhed (art. 1) og en lovprisning af prædikeembedet (art. 4). Betoningen af nødvendigheden af tidshistoriske studier for forståelsen af den specifikke betydning i Bibelens forskellige skrifter findes side om side med understregningen af, at Kristus er Skriftens egentlige mål, og den som hele Skriften taler om, fordi det er ved ham, den er givet (art. 209f).

Tractatus viser samtidig Gerhard som en stor kender af den samtidige katolske teologi. Således indeholder værket lange metodisk begrundede tilbagevisninger af Bellarmin og Stapleton, som der i bogen er flere henvisninger til end til Luther. Sidstnævnte spiller dog selvsagt ingenlunde nogen lille rolle. De servo arbitrio viser sig tværtimod ikke overraskende at indtage en central position i udviklingen af ortodoksiens skriftprincip. Mere skjult er brugen af Matthias Flacius' Clavis, som dog indholdsmæssigt er stærkt fremtrædende - også flere steder end de eksplicit fremgår. Tractatus er derfor også et eksempel på den i eftertiden næsten forkætrede Flacius' betydning for lutherdommens udvikling.

Navnlig bønnebogen Exercitium pietatis påkalder sig opmærksomhed. Det skyldes ikke kun den store virkningshistorie, som også Friedrich Fabri- 
cius' koraludgaver af bønnebogen udgivet i 1688 som Praxis Pietatis Gerhardi melica vidner om. Teksten til disse koraludgaver er medtaget i dette bind, hvor de fylder ca. halvdelen. Det skyldes også, at ortodoksiens bønnebogslitteratur bidrager til at nuancere det ofte fortegnede billede af den lutherske ortodoksi og gøre forbindelsen til den senere pietisme tydelig. Samtidig viser den også, hvordan den lutherske ortodoksi viderefører bestemte træk i den lutherske teologi på bekostning af andre og dermed bidrager til udviklingen af reformationsteologien. Illustrativ er fx bønnebogens opbygning. Den er delt i fire dele: 1. del om betragtningen af egen synd, 2. del om betragtningen af de guddommelige velgerninger, hvor taknemmeligheden spiller en gennemgående rolle, 3. del om betragtningen af egen nød, der er mere end dobbelt så lang som 4. del om næstens nød. Med sin firdeling lægger Gerhard sig delvist op ad det forslag til en katekismusdispositoin, som Luther med udgangspunk i sondringen mellem tro og kærlighed (jf. her art. 61 i De legitima Scriptura) selv angiver i indledningen til Deutsche Messe fra 1526 (jf. WA 19,77), men som Luther, da han selv begynder at skrive katekismer i 1529 alligevel fravælger til fordel for en disposition, der følger de tre hovedstykker, dekalog, credo og fadervor. At struktureringen på ingen måde er ligegyldig, vil en dyberegående sammenligning af Luthers katakismer og Gerhards bønnebog utvivlsomt vise. Hvor Luther begynder med positivt at udlægge dekalogens negative forbud, som anvisninger på hvorledes det skabte liv bør leves, og i den store Katekismus forklarer Gudsbegrebet ud fra forståelsen af troen som tillid, begynder Gerhard negativt med syndserkendelsen - med mindre man inddrager fortalen i fortolkningen og dér læser, at en from bøn, der vokser ud af tro, er en venskabelig samtale med Gud og en åbning af Paradis. På den baggrund kan også den første syndsbekendende del stå under positivt fortegn. Bønnens første retningspil er derfor Guds almægtige godhed, der giver goder, førend nogen beder om dem. Hvad der altså også gælder den syndsbekendende bøn, selvom det ikke nævnes eksplicit. I bønnebogens anden del om Guds generøsitet, er det derimod et gennemgående træk. En henvisning til forbindelsen mellem Luthers katekismusovervejelser og Gerhards bønnebogsdisposition savnes dog i noteapparatet, der i øvrigt - sandsynligvis af trykketekniske grunde - også gemmer de bibelhenvisninger, som i originalen er anført i marginen.

Som Luther, har Gerhard ingen problemer med at beskrive og illustrere forholdet mellem Gud og mennesker med formuleringer og billeder, der indeholder en betydelig grad af gensidighed, netop fordi forudsætningen er Guds altid og alting forudgående given. Således spiller offertanken en gennemgående rolle i første del om betragtningen af egen synd. I hver enkelt afgrænsede og detaljerede syndsbekendelse finder man den bekendende synders ofring af enten Jesu velgerninger: ( $\mathrm{fx}$ Jesu undfangelse som betaling for synderens fordærvede natur, og Jesu lydighed for ungdommens synder) eller af egen suk og klage. Der er her intet forbehold over for brugen af begreber 
som offer og betaling og Gerhard trækker her på den tankegang, som vi også finder i Melanchthons fremhævelse af Kristi velgerninger - transaktionsdimensionen er dog hos Gerhard betydeligt mere fremtrædende - og forbindes med tanken om Guds altid forudgående given, som vi finder hos såvel Luther som Melanchthon. Denne given er dog ikke på samme måde som hos Luther fremhævet som udtryk for guddommelig selvhengivelse. Giver og gave falder hos Gerhard ikke entydigt sammen, og Gerhard minder her mere om Melanchthon.

Tilsammen er disse to bøger en væsentlig kilde til forståelsen af den tidligste ortodoksi. De vil sandsynligvis bidrage til at nuancere ortodoksi-begrebets brugbarhed og dermed understøtte tendenserne imod erstatningen af dette begreb med begrebet om konfessionalisering.

Bo Kristian Holm

\section{Andreas Stegmann}

Johann Friedrich König. Seine Theologia positiva acroamatica (1664) im Rahmen des frühneuzeitlichen Theologiestudiums. Beiträge zur historischen Theologie 137. Tübingen: Mohr Siebeck 2006. VIII + 318 s. € 49.

\section{Johann Friedrich König}

Theologia positiva acroamatica (Rostock 1664). Red. og oversat af Andreas Stegmann. Tübingen: Mohr Siebeck 2006. VI + 520 s. € 79.

Johann Friedrich König (1619-1664) er ikke en af den lutherske ortodoksis mest produktive teologer. Han dør meget tidligt. Alligevel får han stor indflydelse takket været hans eneste større bog, der udgives i hans dødsår: Theologia Positiva Acroamatica. Denne bog fremstiller den dengang samtidige lutherske teologi på en systematisk måde (i dens "antisynkretistiske" variant, sådan som den kendes fra Leipzig og Wittenberg, hvor König fik sin akademisk skoling, jf. St. 1,7-26), men til forskel fra andre berømte systematiske fremstillinger ( $\mathrm{fx}$ fra Gerhard eller Baier) er værket ganske kortfattet. Königs Theologia bliver en af den lutherske teologis mest succesrige dogmatiske lærebøger. Den læses på seminarer til omkring 1750 (St. 201-224). Karakteristisk for bogens succes bliver den grundlaget for Quenstedts Theologia Didactico-Polemica Sive Systema Theologicum (1685), jf. St. 210-211. Men bogen har også en "anden virkningshistorie” (St. 225), hvor König forstås som en typisk repræsentant for den "lutherske skolastik", og det sædvanligvis i en negativ forstand. Alpha illud Orthodoxiae metaphysicae bliver han - nedsættende - kaldt i et pietistisk tidsskrift fra 1709 (St. 225), og Budde skriver i sin Isagoge Historico-Theologica (1730), at König kun fremstiller teologien som en benrad uden saft og blod (St. 234: sceleton ... succo omni et sanguine destitutum). For den repristinerende lutherske teologi i det 19. århundrede var Königs bog tilsyneladende ikke så vigtig som fx Gerhards, Baiers, Quenstedts fremstillinger (den sidste afhænger af König!) og - fremfor alt - Hollazs Examen Theologicum Acroamaticum (1707). Hase citerer ham nogle 